\title{
Biology of non-native species (Rhaphiodon vulpinus Agassiz, 1829) (Characiformes, Cynodontidae) in a cage fish farm area, Upper Paraná River Basin, Brazil
}

Biologia de espécie não-nativa (Rhaphiodon vulpinus Agassiz, 1829, Characiformes, Cynodontidae) em área de piscicultura em tanques-rede, Bacia do Alto Rio Paraná, Brasil

Aymar Orlandi Neto ${ }^{1 *}$ (D), Lidiane Franceschini ${ }^{1}$ (D), Letícia de Oliveira Manoel ${ }^{1}$ (D), Rosicleire Veríssimo-Silveira ${ }^{2}$ (D), Rosilene Luciana Delariva ${ }^{3}$ (D) and Igor Paiva Ramos ${ }^{1,2}$

${ }^{1}$ Programa de Pós-graduação em Ciências Biológicas (Zoologia), Instituto de Biociências, Universidade Estadual Paulista - UNESP, Campus de Botucatu, Rua Professor Doutor Antonio Celso Wagner Zanin, 250, CEP 18618-689, Botucatu, SP, Brasil

${ }^{2}$ Departamento de Biologia e Zootecnia, Faculdade de Engenharia de Ilha Solteira, Universidade Estadual Paulista - UNESP, Campus de Ilha Solteira, Rua Monção, 226, CEP 15385-000, Ilha Solteira, SP, Brasil

${ }^{3}$ Centro de Ciências Biológicas e da Saúde, Universidade Estadual do Oeste do Paraná UNIOESTE, Campus de Cascavel, Rua Universitária, 2069, CEP 85819-110, Cascavel, PR, Brasil *e-mail: orlandi.aymar@gmail.com

Cite as: Orlandi Neto, A. et al. Biology of non-native species (Rhaphiodon vulpinus Agassiz, 1829) (Characiformes, Cynodontidae) in a cage fish farm area, Upper Paraná River Basin, Brazil. Acta Limnologica Brasiliensia, 2019, vol. 31, e9.

Abstract: Aim: To assess the dietary, populational and parasitological aspects of the non-native wild species Rhaphiodon vulpinus in an area under the influence of cage fish farm, in the Ilha Solteira Reservoir, São Paulo State. Methods: Fifty-one specimens of $R$. vulpinus were captured bimonthly, from September 2014 to August 2016, with gill nets with different mesh sizes, in area surrounding a cage fish farm and area not influenced by this activity. The specimens were quantified and their mass $(\mathrm{g})$ and standard length $(\mathrm{cm})$ measured. The stomachs were analyzed with a stereomicroscope and the food items were quantified using the gravimetric method. The parasites were collected during necropsy and their prevalence, mean intensity of infection and mean abundance were subsequently calculated. Results: There were changes in feeding activity regarding the area, with greater numbers of individuals with stomach contents in the areas under the influence of fish farm. However, diet composition did not change between the areas analyzed, with prey represented by small fish, such as Geophagus sveni, and shrimps. In the fish farm area there was also a decrease in abundance and an increase in the total mass of the individuals, while there was no difference in standard length between the areas. In terms of parasitological aspects, low parasitic indexes and the absence of differences between the areas were observed. The first report of the monogenean Notozothecium lamotheargumedoi in the Ilha Solteira reservoir is also presented. Conclusions: The cage fish farm affected some aspects of the population and the food intake of $R$. vulpinus. Furthermore, the parasite-host relationship demonstrated that phylogenetic specificities had a greater effect than aquaculture activity on $R$. vulpinus in the fish farm area.

Keywords: Ilha Solteira reservoir; tilapia production; ichthyofauna; diet; parasites. 
Resumo: Objetivo: Verificar os aspectos alimentares, populacionais e parasitológicos da espécie de peixe silvestre não-nativa Rhaphiodon vulpinus em área sob influência de uma piscicultura em tanques-redes, no reservatório de Ilha Solteira, São Paulo. Métodos: Cinquenta e um exemplares de R. vulpinus foram capturados entre setembro de 2014 e agosto de 2016, com redes de espera com diferentes malhas, em área no entorno de uma piscicultura em tanques-rede e área sem a influência dessa atividade. Os exemplares foram quantificados e suas massas $(\mathrm{g})$ e comprimentos padrão $(\mathrm{cm})$ mensurados. Os estômagos foram analisados em estereomicroscópio e os itens alimentares quantificados por meio do método gravimétrico. Os parasitas foram coletados durante as necropsias, sendo calculados os atributosde prevalência, intensidade média de infecção e abundância média parasitária. Resultados: Houve mudanças na atividade alimentar em relaçáo as áreas, sendo maior o número de indivíduos com conteúdo estomacal na área de piscicultura. Porém, a composição da dieta não se alterou entre as áreas, sendo suas presas pequenos peixes, como Geophagus sveni, e camarão (Macrobrachium sp.). Também na área de piscicultura, verificou-se diminuição da abundância e aumento da massa total dos indivíduos, contudo não houve diferenças no comprimento padrão entre as áreas. Quanto aos aspectos parasitológicos, observou-se baixos índices parasitários e ausência de diferenças entre as áreas. Apresenta-se o primeiro registro do parasita monogenético Notozothecium lamotheargumedoi no reservatório de Ilha Solteira. Conclusóes: A piscicultura afetou alguns aspectos populacionais e a ingestáo de alimento de $R$. vulpinus. Ainda, a relação parasita-hospedeiro demonstrou que as especificidades filogenéticas se sobressaíram aos efeitos oriundos da atividade aquícola sobre $R$. vulpinus na área de piscicultura.

Palavras-chave: reservatório de Ilha Solteira; criação de tilápias; ictiofauna; dieta; parasitas.

\section{Introduction}

Brazil has one of the largest water networks in the world with a freshwater reserve of approximately $12 \%$ of the world total (Silva, 2012). Part of this reserve is located in more than 700 large reservoirs which while important for regional economic development cause major changes in aquatic ecosystems and adjacent landscapes, with consequences for biodiversity (Agostinho et al., 2015; Winemiller et al., 2016). One of these changes is the flooding of natural barriers allowing fish species previously restricted to the lower section of a basin, such as Rhaphiodon vulpinus Agassiz, 1829 (dogfish or golden mache) (Agostinho et al., 2003), to reach the upper section. This species was naturally distributed in the lower and middle Paraná River basin, reaching the upper section after the Salto de Sete Quedas flood which resulted from the formation of the Itaipu Hydroelectric Power Plant reservoir in 1983 (Agostinho et al., 2003). With the formation of reservoirs, the local hydrology is severely altered from a lotic to a lentic condition, with greater volume and water stability in the reservoir body (Agostinho et al., 2007).

The reservoirs has hydrological, logistic and water volume characteristics that provide conditions for the implementation of cage fish farms (Diemer et al., 2010), which have major economic potential, attracting domestic and international investors (Peixe BR, 2018). In 2017, Brazilian fishery production increased $8 \%$ in comparison with the previous year, reaching 691,700 tons of fish, with a production value of 4.7 billion reais (Peixe BR, 2018). Specifically, the Ilha Solteira Reservoir in the Paraná River is the main hub for the production of Nile tilapia (Oreochromis niloticus (Linnaeus, 1758)) in cages in the state of São Paulo (IBGE, 2016). It had an annual production of more than 23,000 tons in 2016, notably in the municipal regions of Santa Fé do Sul, Santa Clara d'Oeste, and Rubinéia, in São Paulo State, and Aparecida do Taboado in Mato Grosso do Sul State, listed among the country's largest tilapia producers (IBGE, 2016).

Cage fish farm systems present great economic and environmental challenges. It is estimated that during tilapia production in cages at least $18 \%$ of feed used is lost to the aquatic environment in the Neotropical region (Montanhini Neto \& Ostrensky, 2015), resulting in economic losses and environmental influences. This entry of allochthonous organic matter into the aquatic ecosystem can contribute to an increase in nitrogen and phosphorus levels, and may affect water quality in areas close to cage fish farms (Sarà, 2007; Montanhini Neto \& Ostrensky, 2015), as well as the trophic status of the environment.

The input of organic matter has been reported in both marine (Sarà, 2007; Mannino \& Sarà, 2008) and freshwater environments (Montanhini Neto \& Ostrensky, 2015; Kliemann et al., 2018), together with alterations in the food chain and modification of the natural diet of wild fishes in areas close to cage fish farms (Ramos et al., 2008; Demétrio et al., 2012; Brandão et al., 2012, 2013; Sanchez-Jerez et al., 2011; Kliemann et al., 2018), local alterations to 
the structure of the wild ichthyofauna (Uglem et al., 2014; Ramos et al., 2013; Nobile et al., 2018) and increases in parasitic infection rates in wild fish (Ramos et al., 2014). Another important environmental influence caused by fish farms is the introduction of non-native species, with at least 32 registered entries (Ortega et al., 2015). Such influences may pose risks to the diversity of native fish through biotic homogenization (Britton \& Orsi, 2012), as well as result in economic risks due to a loss of environmental quality, with a consequent decrease in productivity.

Thus, information on the ecological aspects of wild fish species can assist in the evaluation of environmental influences on aquaculture activity and, consequently, contribute to the development of more sustainable forms of production. The present study tested the following hypothesis: cage fish farm systems modify the dietary, population and parasitological aspects of specimens of $R$. vulpinus from area close to cages in the Ilha Solteira Reservoir.

\section{Material and Methods}

\subsection{Study area}

The Ilha Solteira Reservoir is an accumulation reservoir formed mainly by the Paraná River in the Upper Paraná River basin. It has an average depth of $17.6 \mathrm{~m}$, a maximum volume of $21.06 \times 10^{9} \mathrm{~m}^{3}$, a basin area of $1195 \mathrm{~km}^{2}$ and a residence time of 46.7 days (Garcia et al., 2014). The cage fish farm studied is located in the Can-Can branch of the reservoir (Figure 1). Currently, the cage fish farm studied cultivate Nile tilapia (O. niloticus) and has approximately $23018 \mathrm{~m}^{3}$ cages and $18144 \mathrm{~m}^{3}$ cages, with an approximate daily pelleted feed of $4,375 \mathrm{~kg} \times$ day $^{-1}$. The pelleted feed used contains approximately $32 \%$ crude protein, $10 \%$ mineral matter, $6 \%$ ether extract, $5 \%$ fiber matter, $3.5 \%$ calcium, $1.5 \%$ phosphorus, and vitamins and minerals in smaller proportions (manufacturer's information).

\subsection{Field collection}

The collection of specimens of $R$. vulpinus was performed bimonthly between September 2014 and August 2016 using gill nets with different mesh sizes ( 3 to $16 \mathrm{~cm}$ between nonadjacent knots), exposed from 17:00 h to 07:00 h. Sampling was conducted in two areas with similar characteristics of hydrodynamics and temperature: one area used for cage fish farm activities (cage farm area (CF) $-20^{\circ} 02^{\prime} 30.54$ 'S and 50 55'59.65” W) and the other approximately $10 \mathrm{~km}$ upstream, without the influence of the cage fish farm (control area (CT) $-20^{\circ} 0^{\prime} 13.71^{\prime \prime} \mathrm{S}$ and 5051'58.94”W) (Figure 1).

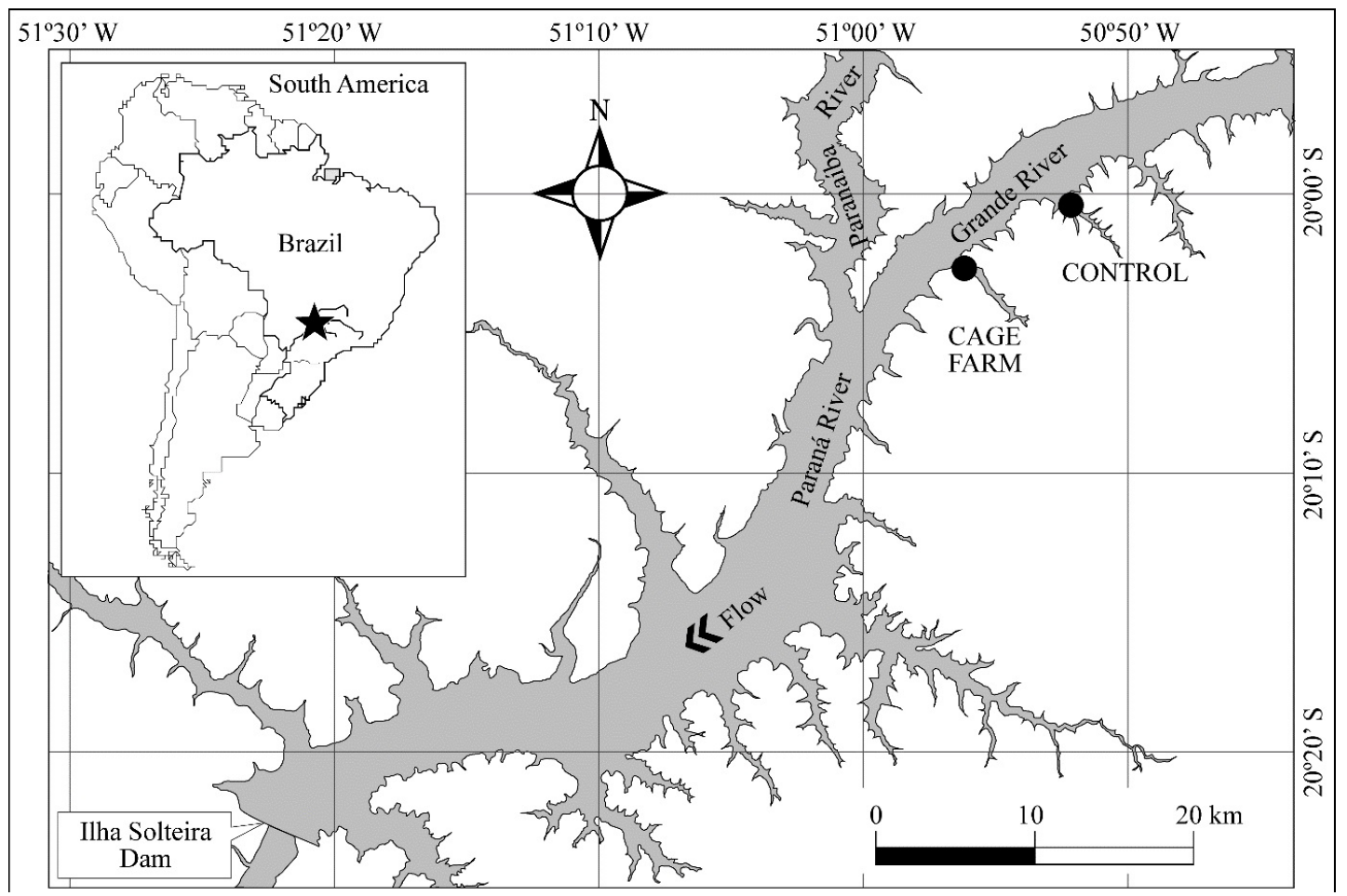

Figure 1. The study area showing the Ilha Solteira Reservoir, with sampled areas in the Grande River, São Paulo, Brazil. Source: Kliemann et al. (2018). 
The collected specimens were individually placed in plastic bags and gradually cooled to rapidly reduced their metabolic activity until death, according to license SISBio 42229-1 and the procedures approved by the Ethics Committee on Animal Experimentation of the Universidade Estadual Paulista "Júlio de Mesquita Filho", UNESP (CEEA - 001/2014).

Voucher specimens of the host fish were deposited in the fish collection of the Universidade Estadual Paulista - UNESP, in the municipalityof São José do Rio Preto, Brazil (DZSJRP 21317). Vouchers of the parasites were deposited in the Helminthological Collection of the Department of Parasitology, Institute of Biosciences, Universidade Estadual Paulista - UNESP (CHIBB), in the municipality of Botucatu, Brazil (Notozothecium lamotheargumedoi 366-375 L; Trematoda (metacercariae) 8479 and Hysterothylacium sp. (larvae) 8480).

\subsection{Laboratory procedures}

The mucus of the specimens was collected in the laboratory and their standard length $(0.1 \mathrm{~cm})$ and total mass $(0.01 \mathrm{~g})$ was measured. A longitudinal incision was subsequently made on the ventral surfaces. The stomachs were removed and fixed in a $4 \%$ formaldehyde solution, while the other organs were frozen until the parasitological analysis.

The stomach contents were examined under an optical stereomicroscope. Food items were identified using Mugnai et al. (2010) for invertebrates and Ota et al. (2018) for fishes. The food items were quantified using the gravimetric method, and the wet mass was recorded with a precision analytical balance $(0.0001 \mathrm{~g})$. To reduce the influence of fish size on the diet composition results, the relative mass (WAG $=$ MI.MT $^{-1}$ ) method proposed by Ahlbeck et al. (2012) was applied, where: $\mathrm{MI}=$ mass of the food item, MT = fish mass. The composition of the diet in each area was expressed by the percentage of the mass of each food item consumed in relation to the total mass consumed.

The mucus and all the organs were examined individually with the aid of stereomicroscopy to verify the presence and recovery of parasites. All the parasites found were fixed and preserved in 70\% ethanol solution, and then processed according to Eiras et al. (2006). To identify the species, the parasites were analyzed using a computerized system for image analysis with differential interference contrast (DIC) - LAS V3 (Leica Application Suite). Prevalence (P), mean intensity of infection (MII) and mean abundance (MA) were obtained according to Bush et al. (1997) for all the registered parasite taxa.

\subsection{Data analysis}

To test for possible significant differences in the number of fish with stomach contents at time of capture and the relative numeric abundance of fish between the CF and CT areas, the $\chi^{2}$ test (chi-square) was applied. The standard length, total weight, mean intensity of infection and mean abundance values of the sampling areas were compared with the Mann-Whitney test (U-Test) and prevalence was compared with the $\mathrm{Z}$ test. To test differences in diet composition between the CF and CT areas, permutational multivariate analysis of variance (PERMANOVA one-way) was applied using the Bray-Curtis Index, with 9999 random permutations (Anderson, 2001). For all statistical analyses, a value of $p<0.05$ was adopted as the threshold for significance and the PAST 3.0 and SigmaStat 4.0 software packages were used.

\section{Results}

\subsection{Diet}

Fifty-one specimens of $R$. vulpinus were analyzed (CF = 19 and CT 32 specimens). A significant difference was observed in the percentage of individuals with the presence of stomach contents at the time of capture, with the highest values observed in the CF area $\left(\mathrm{CF}=63.1 \%\right.$ and $\mathrm{CT}=37.5 \%-\chi^{2}=6.5876$, $p<0.05)$. The diet of $R$. vulpinus did not differ significantly between the areas (Permanova one-way $\mathrm{DF}=1, p=0.403, \mathrm{~F}=0.928)$ and was characterized mainly by the presence of small fish, including Geophagus sveni Lucinda, Lucena \& Assis, 2010 (= Geophagus proximus for Paraná River basin, a non-native species), fragments of unidentified fish, Decapoda (Macrobrachium sp.), and Odonata nymphs (Table 1). The presence of aquatic plants and terrestrial insects in the diet of specimens from the CT area was also verified

\subsection{Population biology}

Rhaphiodon vulpinus had higher total mass $(\mathrm{p}=0.0009, \mathrm{U}=133.00)$ and less relative numerical abundance $\left(\chi^{2}=6.5025, p<0.05\right)$ values in the CF area, while standard length did not differ between areas $(p=0.30, \mathrm{U}=251.50)$ (Table 2$)$.

\subsection{Parasitological aspects}

Two clades of parasitic organisms were recorded for each area evaluated. Notozothecium lamotheargumedoi Cohen \& Kohn, 2008 (Monogenea) was recorded 
in both areas. Four specimens from the CF area were infected with unidentified metacercariae (Trematoda) found in the heart, while one host from the CT area was parasitized by a third-stage larvae of Hysterothylacium sp. (Nematoda) (Table 3). However, no differences were observed between the areas for prevalence $(p=0.22, \mathrm{Z}=1.227)$, mean intensity of infection $(p=0.45, t=-0.79)$ and average abundance $(p=0.28, \mathrm{U}=249.50)$. There was also no difference in the parasite component communities between the $\mathrm{CF}$ and $\mathrm{CT}$ areas (Permanova one-way DF $=1, p=0.21, \mathrm{~F}=1.573$ ).

\section{Discussion}

Recent studies on fish dietary changes related to influence of cage fish farms showed that the omnivorous species that occupy these areas tend to make use of the nutrients provided by fish farms, whether in the form of feed or the feces of cultivated animals (Håkanson, 2005; Ramos et al., 2008, 2013; Kliemann et al., 2018). In the case of the carnivorous species resident in these areas, dietary changes are indirect reflexes of the entry of organic matter into the aquatic ecosystem (Ramos et al., 2013). These effects can also increase the productivity of the periphyton (Mannino \& Sarà, 2008), which has the consequence of increasing the biomass of small fish (Ramos et al., 2008, 2013; Brandão et al., 2012) and aquatic invertebrates (Agostinho et al., 2007), as potential prey. Changes in the piscivorous diet, specifically, may also occur through the predation of cultured fish that escape from fish ponds (Serra-Llinares et al., 2013). Thus, the abundance of wild piscivorous fish in the vicinity of fish farms may reduce the survival rates of the fish from escape (Uglem et al., 2014).

Table 1. Food items consumed by Rhaphiodon vulpinus in the Ilha Solteira Reservoir, Upper Paraná River basin, Brazil. Values are based on percentages of the weight of food items.

\begin{tabular}{ccc}
\hline Local & Control & Cage farm \\
\hline Abundance & $\mathbf{3 2}$ & $\mathbf{1 9}$ \\
\hline Analyzed stomach & $\mathbf{1 2}$ & $\mathbf{1 3}$ \\
\hline Length class ranges (cm) & $\mathbf{2 3 . 1 0 - 4 4 . 0 0}$ & $\mathbf{2 3 . 0 0 - 4 7 . 6 0}$ \\
\hline Food item & Weight (\%) & Weight (\%) \\
\hline Fish Decapoda (Macrobrachium sp.) & 51.33 & 69.99 \\
& 38.63 & 27.81 \\
Odonata & 8.38 & 2.18 \\
Vegetable & 1.60 & - \\
Terrestrial Insects & 0.05 & - \\
\hline
\end{tabular}

Table 2. Relative numeric abundance and medians for total weight and standard length \pm interquartile deviation of Rhaphiodon vulpinus in the Ilha Solteira Reservoir, Upper Paraná River basin, Brazil.

\begin{tabular}{lcc}
\hline \multicolumn{1}{c}{ Populational attributes } & \multicolumn{2}{c}{ Local } \\
\cline { 2 - 3 } & Control & Cage farm \\
\hline Relative numeric abundance $(\%)$ & ${ }^{*} 62.75$ & 37.25 \\
Total weight $(\mathrm{g})$ & $316.01 \pm 69.17$ & ${ }^{*} 412.14 \pm 132.23$ \\
Standard length $(\mathrm{cm})$ & $38.85 \pm 2.37$ & $39.10 \pm 4.56$ \\
\hline
\end{tabular}

*Significant differences $(\mathrm{p}<0.05)$.

Table 3. Prevalence, mean intensity of infection and mean abundance of parasites (mean \pm standard error) of Rhaphiodon vulpinus in the Ilha Solteira Reservoir, Upper Paraná River basin, Brazil.

\begin{tabular}{|c|c|c|c|c|c|c|c|}
\hline \multirow[t]{2}{*}{ Parasites } & \multirow{2}{*}{$\begin{array}{l}\text { Infection } \\
\text { local }\end{array}$} & \multicolumn{2}{|c|}{ Prevalence (\%) } & \multicolumn{2}{|c|}{$\begin{array}{c}\text { Mean intensity of } \\
\text { infection }\end{array}$} & \multicolumn{2}{|c|}{ Mean abundance } \\
\hline & & CT & CF & CT & CF & CT & CF \\
\hline $\begin{array}{l}\text { Notozothecium } \\
\text { lamotheargumedoi }\end{array}$ & Mucus/gills & 9.37 & 26.31 & $2.33 \pm 0.66$ & $3.20 \pm 0.73$ & $0.21 \pm 0.13$ & $0.84 \pm 0.37$ \\
\hline $\begin{array}{l}\text { Trematoda } \\
\text { (metacercariae) }\end{array}$ & Heart & - & 21.05 & - & $1.50 \pm 0.57$ & - & $0.31 \pm 0.67$ \\
\hline $\begin{array}{l}\text { Hysterothylacium sp. } \\
\text { (larvae) }\end{array}$ & Intestine & 3.12 & - & 1.00 & - & $0.02 \pm 0.17$ & - \\
\hline
\end{tabular}

$\mathrm{CT}=$ control area; $\mathrm{CF}=$ cage farm area. 
The diet of $R$. vulpinus did not change in areas surrounding the cage fish farm. This may be due to the fact that its main prey such as small-fish (G. sveni) (Gois et al., 2015) and shrimp (Macrobrachium sp.) (Magalhães et al., 2005), were abundant in the two study areas. Rhaphiodon vulpinus is considered a piscivore species whose diet changes little due to alterations in the aquatic community (Pereira et al., 2017). However, the high abundance of shrimp recorded in diet indicates an opportunistic trait, suggesting dietary flexibility based on the preferential resources available in the environment (Abelha et al., 2001), a food tactic typical of opportunistic piscivorous species (Kahilainen \& Lehtonen, 2003). In addition, the presence of vegetation as an item consumed in the CT area is possibly attributed to the stomach contents of the prey (in this case, fish) or accidental consumption by prey living in the marginal vegetation (Pacheco et al., 2009).

It is not uncommon to find a high incidence of empty stomachs among this species, as its prey is relatively large, high nutritional value and easily digestible, reducing the time needed to reach satiety (Pacheco et al., 2009; Ferriz et al., 2016). This characteristic makes it difficult to study the diet of piscivorous species, not only due to the incidence of discharge of empty stomachs but also the rapid digestion of prey (Hahn et al., 1999; Pacheco et al., 2009). In addition, the lower presence of stomachs with contents in the CT area may be the result of the higher percentage of shrimp consumed in this area. Such a resource, despite a high degree of nutrient digestibility through emptying, and also the rapid digestion of prey (Boscolo et al., 2004), is smaller in size and has a softer body than fish prey (Goulding \& Ferreira, 1984), leading to the rapid digestion of food (Jobling, 1987). The higher percentage of individuals with stomach contents and the greater total mass of $R$. vulpinus in the CF area may, on the other hand, indicate a possible relationship with aquaculture activity. This is due to the fact that increasing the density of small fish and crustaceans in surrounding areas (Ramos et al., 2008, 2013; Brandão et al., 2013) may favor the success of foraging predators, which may accumulate greater body reserves (Luz-Agostinho et al., 2009; Petenuci et al., 2016).

The densification of prey in the CF area did not reflect a greater numerical abundance of $R$. vulpinus. This fact may reflect interspecific competition with other carnivorous species, such as the non-native wild species Plagioscion squamosissimus (Heckel, 1840), which presented greater numerical abundance in the CF area $(n=487)$ than the CT $(n=307)$ (personal information). Both species have pelagic habits and pursuit predation in common (Luz-Agostinho et al., 2008). Moreover, P. squamosissimus is characterized as opportunistic piscivorous in the Upper Paraná River (Bennemann et al., 2006) with high trophic overlap between the two species (Luz-Agostinho et al., 2008). Thus, the overlapping relationships between top predator species may structure the abundance of $R$. vulpinus in the CF area.

In terms of parasitological aspects, low species richness was registered for $R$. vulpinus (three taxa), with only $N$. lamotheargumedoi (Monogenea) recorded in both areas, representing the first report of this species in the Ilha Solteira Reservoir. The presence of trematodes and the nematode of the genus Hysterothylacium, both in an immature form, were previously recorded for $R$. vulpinus by Moravec et al. (1993). Although their prevalence and intensity of infection was low. Third-stage larvae of Hysterothylacium sp. have zoonotic potential (Felizardo et al., 2009), with sanitary care required regarding human consumption. In the present study, the recording of this nematode in the larval stage only indicates that $R$. vulpinus acts as a paratenic and/or intermediate host in the areas studied, and piscivorous birds and aquatic mammals often are definitive hosts (Marcogliese, 2002). Due to the cage fish farm activity, there is an increase of the organic matter in the sediment and attraction of the local biota, including potencial hosts to the parasites (Almeida Rodrigues et al., 2013; Ramos et al., 2014). The occurrence of trematodes in the CF area may be related to the attraction of intermediate hosts (as mollusks and other invertebrates) and definitive hosts (piscivorous birds and aquatic mammals) which often compose the biological cycle of trematodes. In both cases, $R$. vulpinus occupies an intermediate position in the trophic web (Marcogliese, 2002; Karling et al., 2013) and can serve as a link between the aquatic and terrestrial environment.

The low parasitic indexes and absence of difference between the CT and CF areas, in relation to the infestation caused by monogeneans, may be related to the fact that $R$. vulpinus is a non-native species in the Upper Paraná River basin. The parasite specificity in relation to its preferencial host and the coevolutionary relationship between parasites and hosts may also be a factor (Poulin \& Morand, 2004). Subpopulations that occur in the study area are therefore derived from small sets of subpopulations 
that have translocated from their place of origin, and may have a low rate of infestation, allowing a reduction in abundance of parasites in the new colonized site (Torchin et al., 2002, 2003). Another important aspect is related to the high specificity of a particular host species, or species with high phylogenetic proximity (Thatcher, 2006). ,The fact that a host species belongs to a more diverse clade may can reflectin a great parasite richness, and the reverse may also occur, as in the case of $R$. vulpinus, the only representative of the Cynodontidae family in the Upper Paraná River basin (Ota et al., 2018), a factor which could explain the low parasite richness (Nunn et al., 2004; Poulin \& Morand, 2004).

It can be concluded that the presence of cage fish farm caused changes in the biological aspects of $R$. vulpinus, with a greater number of individuals with stomach contents in this area, probably due to the greater abundance of prey, which consequently favored the increase of the total mass of this species. Despite this, the interaction with piscivorous competitors of the same trophic level may have caused the dispersion of $R$. vulpinus to other areas, reducing its abundance in the area adjacent to the fish farm. The low prevalence, mean intensity of infection, and mean abundance of parasites observed for this non-native species, are more related to phylogenetic specificities and coevolutionary relationship between parasites and hosts than to the densification of the fauna caused by fish culture.

\section{Acknowledgements}

This study was supported by $\mathrm{CNPq}$ (Conselho Nacional de Desenvolvimento Científico e Tecnológico - process number 443103/2014-3) and Fundunesp (Fundação para o Desenvolvimento da UNESP - process number 0305/001-14 Prope-CDC). The authors would like to thank CAPES (Coordenação de Aperfeiçoamento de Pessoal de Nível Superior) for financial and scientific support and the post-graduate scholarships granted to L.F (CAPES/PNPD 17/2016), as well as the Faculdade de Engenharia de Ilha Solteira (FEIS), São Paulo State University - UNESP, the Laboratório de Ictiologia Neotropical (LINEO-FEIS/UNESP), and the Instituto de Biociências de Botucatu (IBB/UNESP) for the use of laboratory facilities and logistics, the Laboratório de Parasitologia de Animais Silvestres (LAPAS-IBB/UNESP) and Prof. Francisco Langeani Neto for fish identification (IBILCE/UNESP). I.P.R. is supported by Conselho
Nacional de Desenvolvimento Científico e Tecnológico (CNPq) (process 303311/2018-5).

\section{References}

ABELHA, M.C.F., AgOsTinho, A.A. and GOULART, E. Plasticidade trófica em peixes de água doce. Acta Scientiarum, 2001, 23(2), 425-434.

AGOstinho, A.A., GOMES, L.C. and PELICICE, F.M. Ecologia e manejo de recursos pesqueiros em reservatórios do Brasil. Maringá: Eduem, 2007, 501 p.

AgOSTINHO, A.A., GOMES, L.C., SANTOS, N.C., ORTEGA, J.C. and PELICICE, F.M. Fish assemblages in neotropical reservoirs: colonization patterns, impacts and management. Fisheries Research, 2015, (173), 26-36.

AGOSTINHO, A.A., GOMES, L.C., SUZUKI, H.I. and JÚLIO, H.F. Migratory fish from the upper Paraná River basin, Brazil. In: J. CAROLSFELD, B. HARVEY, C. ROSS, A. BAER and C. ROSS, eds. Migratory fishes of South America: biology, social importance and conservation status. Victoria: World Fisheries Trust, the World Bank and the International Development Research Centre, 2003, pp. 19-99.

AHLBECK, I., HANSSON, S. and HJERNE, O. Evaluating fish diet analysis methods by individualbased modelling. Canadian Journal of Fisheries and Aquatic Sciences, 2012, 69(7), 1184-1201. http:// dx.doi.org/10.1139/f2012-051.

ALMEIDA RODRIGUES, L., LEUCHTENBERGER, C., KASPER, C.B., CARVALHO JUNIOR, O. and SILVA, V.C.F. Avaliaçấo do risco de extinçấo da lontra neotropical Lontra longicaudis (Olfers, 1818) no Brasil. Biodiversidade Brasileira, 2013, (1), 216-227.

ANDERSON, M.J. A new method for non-parametric multivariate analysis of variance. Austral Ecology, 2001, 26(1), 32-46.

ASSOCIAÇÃO BRASILEIRA DA PISCICULTURA - Peixe BR. Anuário da piscicultura 2018 [online]. Laguna: Aquaculture Brasil, 2018 [viewed 12 May 2018]. Available from: http://www.aquaculturebrasil. com/2018/02/19/peixe-br-lanca-oanuario-dapiscicultura-2018/

BENNEMANN, S.T., CAPRA, L.G., GALVES, W. and SHIBATTA, O.A. Dinâmica trófica de Plagioscion squamosissimus (Perciformes, Sciaenidae) em trechos de influência da represa Capivara (rios Paranapanema e Tibagi). Iheringia, Série Zoologia, 2006, 96(1), 115-119. http://dx.doi.org/10.1590/ S0073-47212006000100020.

BOSCOLO, W.R., HAYASHI, C., MEURER, F., FEIDEN, A. and BOMBARDELLI, R.A. Digestibilidade aparente da energia e proteína das farinhas de resíduo da filetagem da tilápia do Nilo (Oreochromis niloticus) e da corvina (Plagioscion squamosissimus) e farinha integral do camarão canela (Macrobrachium amazonicum) para a tilápia 
do Nilo. Revista Brasileira de Zootecnia, 2004, 33(1), 8-13. http://dx.doi.org/10.1590/S151635982004000100002 .

BRANDÃO, H., LOBÓN-CERVIÁ, J., RAMOS, I.P., SOUTO, A.C., NOBILE, A.B., ZICA, E.O.P. and CARVALHO, E.D. Influence of a cage farming on the population of the fish species Apareiodon affinis (Steindachner, 1879) in the Chavantes reservoir, Paranapanema River SP/PR, Brazil. Acta Limnologica Brasiliensia, 2012, 24(4), 438-448. http://dx.doi. org/10.1590/S2179-975X2013005000012.

BRANDÃO, H., NOBILE, A.B., SOUTO, A.C., RAMOS, I.P., SOUSA, J.Q. and CARVALHO, E.D. Influence of cage fish farming on the diet and biological attributes of Galeocharax knerii in the chavantes reservoir, Brazil. Boletim Instituto da Pesca, 2013, 39(2), 157-167.

BRITTON, J.R. and ORSI, M.L. Non-native fish in aquaculture and sport fishing in Brazil: economic benefits versus risks to fish diversity in the upper River Paraná Basin. Reviews in Fish Biology and Fisheries, 2012, 22(3), 555-565. http://dx.doi.org/10.1007/ s11160-012-9254-x.

BUSH, A.O., LAFFERTY, K.D., LOTZ, J.M. and SHOSTAK, A.W. Parasitology meets ecology on its own terms: Margolis et al. revisited. The Journal of Parasitology, 1997, 83(4), 575-583. http://dx.doi. org/10.2307/3284227. PMid:9267395.

DEMÉTRIO, J.A., GOMES, L.C., LATINI, J.D. and AGOSTINHO, A.A. Influence of net cage farming on the diet of associated wild fish in a Neotropical reservoir. Aquaculture, 2012, 330333, 172-178. http://dx.doi.org/10.1016/j. aquaculture.2011.11.026.

DIEMER, O., NEU, D.H., FEIDEN, A., LORENZ, E.K., BITTENCOURT, F. and BOSCOLO, W.R. Dinâmica nictimeral e vertical das características limnológicas em ambiente de criação de peixes em tanques-rede. Ciência Animal Brasileira, 2010, 11(1), 24-31. http://dx.doi.org/10.5216/cab.v11i1.6754.

EIRAS, J.C., TAKEMOTO, R.M. and PAVANELLI, G.C. Métodos de estudo e técnicas laboratoriais em parasitologia de peixes. 2. ed. Maringá: Nupélia, 2006, 199 p.

FELIZARDO, N.N., KNOFF, M., PINTO, R.M. and GOMES, D.C. Larval anisakid nematodes of the flounder, Paralichthys isosceles Jordan, 1890 (Pisces: Teleostei) from Brazil. Neotropical Helminthology, 2009, 3(2), 57-64.

FERRIZ, R.A., ARRIETA, P.M. and DOMÁNICO, A.A. Caracterización trófica de nueve especies de peces en los tramos Medio y Bajo del río Uruguay. Histoire et Nature, 2016, 6(1), 41-53.

GARCIA, F., KIMPARA, J.M., VALENTI, W.C. and AMBROSIO, L.A. Emergy assessment of tilapia cage farming in a hydroelectric reservoir. Ecological
Engineering, 2014, 68(1), 72-79. http://dx.doi. org/10.1016/j.ecoleng.2014.03.076.

GOIS, K.S., PELICICE, F.M., GOMES, L.C. and AGOSTINHO, A.A. Invasion of an Amazonian cichlid in the Upper Paraná River: facilitation by dams and decline of a phylogenetically related species. Hydrobiologia, 2015, 746(1), 401-413. http://dx.doi. org/10.1007/s10750-014-2061-8.

GOULDING, M. and FERREIRA, E.J.G. Shrimpeating fishes and a case of prey-switching in Amazon rivers. Revista Brasileira de Zoologia, 1984, 2(3), 85-97.

HAHN, N.S., LOUREIRO, V.E. and DELARIVA, R.L. Atividade alimentar da curvina Plagioscion squamosissimus (Heckel, 1984) (Perciformes, Sciaenidae) no rio Paraná. Acta Scientiarum, 1999, 21(2), 309-314.

HÅKANSON, L. Changes to lake ecosystem structure resulting from fish cage farm emissions. Lakes and Reservoirs: Research and Management, 2005, 10(1), 71-80. http://dx.doi.org/10.1111/j.14401770.2005.00253.x.

INSTITUTO BRASILEIRO DE GEOGRAFIA E ESTATÍSTICA - IBGE. Produção pecuária municipal. Rio de Janeiro: IBGE, 2016, pp. 1-51. no. 44.

JOBLING, M. Influences of food particle size and dietary energy content on patterns of gastric evacuation in fish: test of a physiological model of gastric emptying. Journal of Fish Biology, 1987, 30(3), 299-314. http:// dx.doi.org/10.1111/j.1095-8649.1987.tb05754.x.

KAHILAINEN, K. and LEHTONEN, H. Piscivory and prey selection of four predator species in a whitefish dominated subarctic lake. Journal of Fish Biology, 2003, 63(3), 659-672. http://dx.doi.org/10.1046/ j.1095-8649.2003.00179.x.

KARLING, L.C., LACERDA, A.C.F., ALVARENGA, F.M.S., TAKEMOTO, R.M. and PAVANELLI, G.C. Endoparasites of Rhaphiodon vulpinus (Characiformes: Cynodontidae) and their relation to the standard length and sex of their hosts. Bioscience Journal, 2013, 29(5), 1312-1316.

KLIEMANN, B.C.K., DELARIVA, R.L., AMORIM, J.P.A., SILVA RIBEIRO, C., SILVA, B., SILVEIRA, R.V. and RAMOS, I.P. Dietary changes and histophysiological responses of a wild fish (Geophagus cf. proximus) under the influence of tilapia cage farm. Fisheries Research, 2018, 204(1), 337-347. http:// dx.doi.org/10.1016/j.fishres.2018.03.011.

LUZ-AgOSTINHO, K.D., AGOSTINHO, A.A., GOMES, L.C. and JÚLIO JUNIOR, H.F. Influence of flood pulses on diet composition and trophic relationships among piscivorous fish in the upper Paraná River floodplain. Hydrobiologia, 2008, 607(1), 187-198. http://dx.doi.org/10.1007/s10750-008$9390-4$ 
LUZ-AGOSTINHO, K.D.G., AGOSTINHO, A.A., GOMES, L.C., JÚLIO JUNIOR, H.F. and FUGI, R. Effects of flooding regime on the feeding activity and body condition of piscivorous fish in the Upper Paraná River floodplain. Brazilian Journal of Biology = Revista Brasileira de Biologia, 2009, 69(2), 481-490, Supplement. http://dx.doi.org/10.1590/S151969842009000300004. PMid:19738956.

MAGALHÂES, C., BUENO, S.L.S., BONDBUCKUP, G., VALENTI, W.C., SILVA, H.L.M., KIYOHARA, F., MOSSOLIN, E.C. and ROCHA, S.S. Exotic species of freshwater decapod crustaceans in the state of São Paulo, Brazil: records and possible causes of their introduction. Biodiversity and Conservation, 2005, 14(8), 1929-1945. http://dx.doi. org/10.1007/s10531-004-2123-8.

MANNINO, A.M. and SARÀ, G. Effects of fishfarm biodeposition on periphyton assemblages on artificial substrates in the southern Tyrrhenian Sea (Gulf of Castellammare, Sicily). Aquatic Ecology, 2008, 42(4), 575-581. http://dx.doi.org/10.1007/ s10452-007-9131-1.

MARCOGLIESE, D.J. Food webs and the transmission of parasites to marine fish. Parasitology, 2002, 124(7), S83-S99, Supplement. http://dx.doi.org/10.1017/ S003118200200149X. PMid:12396218.

MONTANHINI NETO, R. and OSTRENSKY, A. Nutrient load estimation in the waste of Nile tilapia Oreochromis niloticus reared in cages in tropical climate conditions. Aquaculture Research, 2015, 46(6), 1309-1322. http://dx.doi.org/10.1111/ are. 12280 .

MORAVEC, F., KOHN, A. and FERNANDES, B.M.M. Nematode parasites of fishes of the Paraná River, Brazil. Part 2. Seuratoidea, Ascaridoidea, Habronematoidea and Acuarioidea. Folia Parasitologica, 1993, 40(1), 115-134.

MUGNAI, R., NESSIMIAN, J.L. and BAPTISTA, D.F. Manual de identificação de macroinvertebrados aquáticos do Estado do Rio de Janeiro. Rio de Janeiro: Technical Boocks, 2010, $174 \mathrm{p}$.

NOBILE, A.B., ZANATTA, A.S., BRANDÃO, B., ZICA, E.O.P., LIMA, F.P.A., FREITAS-SOUZA, D., CARVALHO, E.D., SILVA, R.J. and RAMOS, I.P. Cage fish farm act as a source of changes in the fish community of a Neotropical reservoir. Aquaculture, 2018, 495, 780-785. http://dx.doi.org/10.1016/j. aquaculture.2018.06.053.

NUNN, C.L., ALTIZER, S., SECHREST, W., JONES, K.E., BARTON, R.A. and GITTLEMAN, J.L. Parasites and the evolutionary diversification of primate clades. American Naturalist, 2004, 164(5), S90-S103, Supplement 5. http://dx.doi. org/10.1086/424608. PMid:15540145.

ORTEGA, J.C., JÚLIO, H.F., GOMES, L.C. and AGOSTINHO, A.A. Fish farming as the main driver of fish introductions in Neotropical reservoirs.
Hydrobiologia, 2015, 746(1), 147-158. http://dx.doi. org/10.1007/s10750-014-2025-z.

OTA, R.R., DEPRÁ, G.D.C., GRAÇA, W.J.D. and PAVANELLI, C.S. Peixes da planície de inundaçáo do alto rio Paraná e áreas adjacentes: revised, annotated and updated. Neotropical Ichthyology, 2018, 16(2), e170094. http://dx.doi.org/10.1590/1982-022420170094.

PACHECO, A.C.G., BARTOLETTE, R., CALUCA, J.F., CASTRO, A.L.M., ALBRECHT, M.P. and CARAMASCHI, É.P. Dinâmica alimentar de Rhaphiodon vulpinus Agassiz, 1829 (Teleostei, Cynodontidae) no alto Rio Tocantins (GO) em relaçáo ao represamento pela UHE Serra da Mesa. Biota Neotropica, 2009, 9(3), 1-1. http://dx.doi. org/10.1590/S1676-06032009000300006.

PEREIRA, L.S., TENCATT, L.F.C., DIAS, R.M., OLIVEIRA, A.G. and AGOSTINHO, A.A. Effects of long and short flooding years on the feeding ecology of piscivorous fish in floodplain river systems. Hydrobiologia, 2017, 795(1), 1-16. http://dx.doi. org/10.1007/s10750-017-3115-5.

PETENUCI, M.E., ROCHA, I.D.N.A., DE SOUSA, S.C., SCHNEIDER, V.V.A., COSTA, L.A.M.A. and VISENTAINER, J.V. Seasonal variations in lipid content, fatty acid composition and nutritional profiles of five freshwater fish from the Amazon basin. Journal of the American Oil Chemists' Society, 2016, 93(10), 1373-1381. http://dx.doi.org/10.1007/ s11746-016-2884-8.

POULIN, R. and MORAND, S. Parasite biodiversity. Washington: Smithsonian Institution Press, 2004, $216 \mathrm{p}$.

RAMOS, I.P., BRANDÃO, H., ZANATTA, A.S., ZICA, É.O., SILVA, R.J., REZENDE-AYROZA, D.M. and CARVALHO, E.D. Interference of cage fish farm on diet, condition factor and numeric abundance on wild fish in a Neotropical reservoir. Aquaculture, 2013, 414(1), 56-62. http://dx.doi. org/10.1016/j.aquaculture.2013.07.013.

RAMOS, I.P., FRANCESCHINI, L., ZICA, É.O., CARVALHO, E.D. and SILVA, R.J. The influence of cage farming on infection of the corvine fish Plagioscion squamosissimus (Perciformes: Sciaenidae) with metacercariae of Austrodiplostomum compactum (Digenea: Diplostomidae) from the Chavantes reservoir, São Paulo State, Brazil. Journal of Helminthology, 2014, 88(3), 342-348. http://dx.doi.org/10.1017/S0022149X13000229. PMid:23628163.

RAMOS, I.P., VIDOTTO-MAGNONI, A.P. and CARVALHO, E.D. Influence of cage fish farming on the diet of dominant fish species of a Brazilian reservoir (Tietê River, High Paraná River basin). Acta Limnologica Brasiliensia, 2008, 20(3), 245-252.

SANCHEZ-JEREZ, P., FERNANDEZ-JOVER, D., UGLEM, I., ARECHAVALA-LOPEZ, 
P., DEMPSTER, T., BAYLE-SEMPERE, J., PÉREZ, C., IZQUIERDO, D., BJØRN, P.-A. and NILSEN, R. Coastal fish farms as fish aggregation devices (FADs). In: S.A. BORTONE, F. PEREIRA BRANDINI, G. FABI and S. OTAKE, eds. Artificial reefs in fisheries management. Boca Raton: CRC Press, 2011, pp. 187-208. http://dx.doi.org/10.1201/ b10910-13.

SARÀ, G. A meta-analysis on the ecological effects of aquaculture on the water column: dissolved nutrients. Marine Environmental Research, 2007, 63(4), 390-408. http://dx.doi.org/10.1016/j. marenvres.2006.10.008. PMid:17166578.

SERRA-LLINARES, R.M., NILSEN, R., UGLEM, I., ARECHAVALA-LOPEZ, P., BJØRN, P.A. and NOBLE, C. Post-escape dispersal of juvenile Atlantic cod Gadus morhua from Norwegian fish farms and their potential for recapture. Aquaculture Environment Interactions, 2013, 3(2), 107-116. http://dx.doi.org/10.3354/aei00051.

SILVA, C.H.R.T. Recursos hidricos e desenvolvimento sustentável no Brasil. Brasília: Senado Federal, Consultoria Legislativa, 2012. Boletim do Legislativo, no. 23.

THATCHER, V.E. Amazon fish parasites. 2nd ed. Sofia: Pensoft, 2006, 496 p.

TORCHIN, M.E., LAFFERTY, K.D. and KURIS, M. Parasites and marine invasions. Parasitology, 2002, 124(7), 137-151. http://dx.doi.org/10.1017/ S0031182002001506. PMid:11862992.
TORCHIN, M.E., LAFFERTY, K.D., DOBSON, A.P., MCKENZIE, V.J. and KURIS, A.M. Introduced species and their missing parasites. Nature, 2003, 421(6923), 628-630. http://dx.doi.org/10.1038/ nature01346. PMid:12571595.

UGLEM, I., KARLSEN, O., SÁNCHEZ-JEREZ, P. and SAETHER, B.J. Impacts of wild fishes attracted to open-cage salmonids farms in Norway. Aquaculture Environment Interactions, 2014, 6(1), 91-103. http:// dx.doi.org/10.3354/aei00112.

WINEMILLER, K.O., MCINTYRE, P.B., CASTELLO, L., FLUET-CHOUINARD, E., GIARRIZZO, T., NAM, S., BAIRD, I.G., DARWALL, W., LUJAN, N.K., HARRISON, I., STIASSNY, M.L.J., SILVANO, R.A.M., FITZGERALD, D.B., PELICICE, F.M., AGOSTINHO, A.A., GOMES, L.C., ALBERT, J.S., BARAN, E., PETRERE, M., ZARFL, C., MULLIGAN, M., SULLIVAN, J.P., ARANTES, C.C., SOUSA, L.M., KONING, A.A., HOEINGHAUS, D.J., SABAJ, M., LUNDBERG, J.G., ARMBRUSTER, J., THIEME, M.L., PETRY, P., ZUANON, J., VILARA, G.T., SNOEKS, J., OU, C., RAINBOTH, W., PAVANELLI, C.S., AKAMA, A., SOESBERGEN, A. and SAENZ, L. Balancing hydropower and biodiversity in the Amazon, Congo, and Mekong. Science, 2016, 351(6269), 128129. http://dx.doi.org/10.1126/science.aac7082. PMid:26744397.

Received: 18 September 2018 Accepted: 24 December 2018 